Chicago-Kent College of Law

Scholarly Commons @ IIT Chicago-Kent College of Law

$1-1-2008$

\title{
The Fifth Amendment Disclosure Obligations of Government Employers When Interrogating Public Employees
}

Lindsay Niehaus

Northern Kentucky University Salmon P. Chase College of Law

Follow this and additional works at: https://scholarship.kentlaw.iit.edu/louis_jackson

Part of the Law Commons

\section{Recommended Citation}

Niehaus, Lindsay, "The Fifth Amendment Disclosure Obligations of Government Employers When Interrogating Public Employees" (2008). Louis Jackson National Student Writing Competition. 22. https://scholarship.kentlaw.iit.edu/louis_jackson/22

This Article is brought to you for free and open access by the Institute for Law and the Workplace at Scholarly Commons @ IIT Chicago-Kent College of Law. It has been accepted for inclusion in Louis Jackson National Student Writing Competition by an authorized administrator of Scholarly Commons @ IIT Chicago-Kent College of Law. For more information, please contact jwenger@kentlaw.iit.edu, ebarney@kentlaw.iit.edu. 


\section{THE FIFTH AMENDMENT DISCLOSURE OBLIGATIONS OF GOVERNMENT EMPLOYERS WHEN INTEROGATING PUBLIC EMPLOYEES}

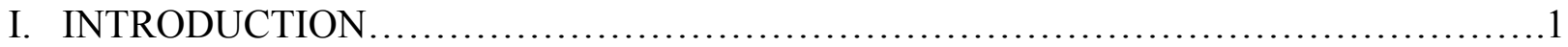

II. BACKGROUND: PUBLIC EMPLOYEE RIGHTS AND IMMUNITIES $\ldots \ldots \ldots \ldots \ldots \ldots \ldots . . . . . . . .$.

A. Fifth Amendment Privilege Against Self-Incrimination.......................... 3

B. Basic Privilege Against Self-Incrimination in the Public Employment Context

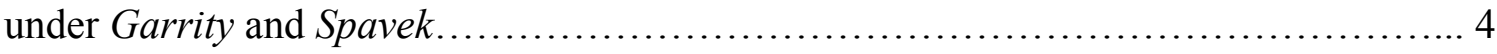

C. Gardner: The Ban on Requiring Waiver of Immunity......................... 5

D. Lekowitz I \& II: The Limited Expansion of Public Employee Rights and Immunities........................................................................ 6

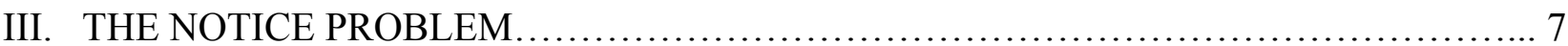

A. The "No Affirmative Tender"," Approach..................................... 8

B. The "Duty to Advise" Approach............................................... 14

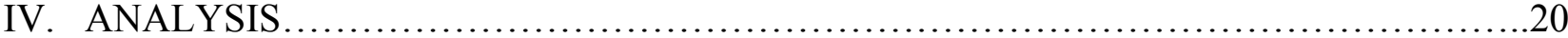

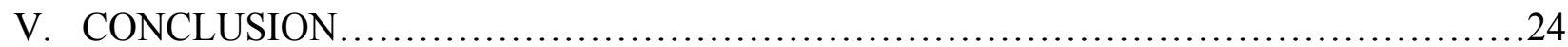

\section{INTRODUCTION}

Imagine you are a police officer working for your local police department. One night while you are on patrol with your partner, you stop at the local doughnut shop. There, you witness your partner not only engage in conversation with a well known drug dealer in the area named Smokey, but also accept an unmarked envelope from him. When your partner returns, he hands you the envelope and asks if you can keep it in your locker for a few days. Despite the suspicious circumstances, you agree and store the envelope.

A few days later, you begin to hear rumors that a few of your fellow officers have been taking bribes from local drug dealers in return for allowing those dealers to pass freely through the city. In response to these allegations, your department opens an investigation and interrogates officers one at a time. When it is your turn to be interrogated, you fear that you will be disciplined because you are still holding the envelope for your partner. Upon entering the interrogation room, the only statement your employer makes is that you must talk or be fired. Unaware that this situation grants you automatic immunity from your self-incriminating 
statements, you fear criminal prosecution and instinctively tell your employer that you are going to exercise your right to remain silent. You are fired on the spot.

Although the Supreme Court has held that public employees must be granted immunity from self-incriminating statements when presented with a choice between answering the employer's questions or facing disciplinary action, the Court has failed to clarify whether the employer must also give the employees notice of their Fifth Amendment rights and immunities prior to asking them potentially incriminating questions. On this issue, the federal circuits are split. The Fifth ${ }^{1}$, Eighth ${ }^{2}$, and Eleventh ${ }^{3}$ Circuits adopt the "no affirmative tender" approach, holding that the government is under no affirmative duty to disclose to employees their rights and immunities prior to questioning. Conversely, the Second ${ }^{4}$, Seventh ${ }^{5}$, and Federal ${ }^{6}$ Circuits adopt the "duty to advise" approach, holding that a government employer is under a duty to advise its employees of their rights and immunities under the Fifth Amendment prior to asking them potentially incriminating questions.

This article argues that the courts should adopt the "duty to advise" approach to a public employer's disclosure obligations. Part II describes the historical evolution of the Supreme Court's decisions regarding the rights and immunities of public employees under the Fifth Amendment. Part III presents the circuit split on the issue of whether the government must give

\footnotetext{
${ }^{1}$ Gulden v. McCorkle, 680 F.2d 1070 (5th Cir. 1982).

${ }^{2}$ Hill v. Johnson, 160 F.3d 469 (8th Cir. 1988).

${ }^{3}$ Hester v. Milledgeville, 777 F.2d 1492 (11th Cir. 1985).

${ }^{4}$ Uniformed Sanitation Men Ass'n v. Commissioner of Sanitation of the City of New York, 426 F.2d $619\left(2^{\text {nd }}\right.$ Cir. 1970).

${ }^{5}$ Atwell v. Lisle Park District, 286 F.3d 987 (7th Cir. 2002).

${ }^{6}$ Modrowski v. Dept. of Veterans Affairs, 252 F.3d 1344 (Fed. Cir. 2001).
} 
employees notice of their rights and immunities under the Fifth Amendment prior to asking them potentially incriminating questions. Part IV analyzes the arguments on both sides of the issue and argues that the "duty to advise" approach is preferable for four reasons. First, it eliminates the potential for public employees to attempt to exercise their constitutional privilege against self-incrimination and unknowingly subject themselves to discipline. Second, it eliminates the potential that the government will use its position of power to manipulate or exploit the employee. Third, the burden imposed on the government in comparison to the protection afforded to the employees would be inherently low. Fourth, it facilitates the government in the process of fact-finding by giving the employees an incentive for honesty.

Part V concludes.

\section{BACKGROUND: PUBLIC EMPLOYEE RIGHTS AND IMMUNITIES}

\section{A. Fifth Amendment Privilege Against Self-Incrimination}

The Fifth Amendment of the United States Constitution states in pertinent part that "No person...shall be compelled to be a witness against himself, nor be deprived of life, liberty or property without due process of law." ${ }^{7}$ The broad scope of the Fifth Amendment affords United States citizens two important rights. ${ }^{8}$ First, it protects individuals from being involuntarily called as witnesses against themselves in a criminal prosecution. ${ }^{9}$ Second, it gives them the privilege not to answer "official questions" put to them in any other proceeding, civil or criminal, formal or informal, where the answers might be self-incriminating in future criminal proceedings. ${ }^{10}$ Basically, the Fifth Amendment affords United States citizens protection from being compelled

\footnotetext{
${ }^{7}$ U.S.C. Const. amend. V.

${ }^{8}$ McCarthy v. Arndstein, 266 U.S. 34, 40 (1924).

${ }^{9}$ Id.

${ }^{10} I d$.
} 
to make self-incriminating statements unless first granted immunity from further prosecution. ${ }^{11}$ Thus, any potentially self-incriminating statement may be used against a citizen only if it is made voluntarily, or without the improper pressures of coercion.

In the 1966 case Miranda v. Arizona, the Supreme Court reinforced this concept and held that "the prosecution may not use statements, whether exculpatory or inculpatory, stemming from custodial interrogation of the defendant unless it demonstrates the use of procedural safeguards effective to secure the privilege against self-incrimination."12 More specifically, any persons that are subject to custodial interrogation must first be given a Miranda Warning, which includes being advised that they have a right to remain silent, that their statements can be used against them in evidence, and that they have a right to an attorney. ${ }^{13}$ The Court further held that these rights may be waived only if the waiver is made "voluntarily, knowingly, and intelligently." ${ }^{14}$ As such, prior to custodial interrogation law enforcement officers must first give a Miranda Warning so as to ensure that citizens are informed of their rights and immunities under the Fifth Amendment.

\section{B. Basic Privilege Against Self-Incrimination in the Public Employment Context under Garrity and Spavek}

Although the Supreme Court clarified the scope of the Fifth Amendment in the typical criminal law context by in Miranda, the extent of the Fifth Amendment rights and immunities of public employees when asked potentially incriminating questions remained unclear. However,

\footnotetext{
${ }^{11}$ Kastigar v. United States, 406 U.S. 441 (1972).

${ }^{12} 384$ U.S. 436, 444.

${ }^{13} I d$.

${ }^{14} I d$.
} 
in 1967, the Supreme Court passed down two opinions on the issue of whether the government can use the threat of discharge to secure incriminatory evidence against an employee.

The Supreme Court first addressed this issue in Garrity v. New Jersey. ${ }^{15}$ There, the police department coerced officers into answering self-incriminating questions by threatening to fire them for refusal to answer. ${ }^{16}$ Consequently, the officers answered the questions, and some of the answers were used in subsequent prosecutions against them. ${ }^{17}$ As such, the officers were presented with the choice between self-incrimination and losing their jobs.

The Court held that the choice presented to the employees amounted to coercion because "the option to lose their means of livelihood or pay the penalty of self-incrimination is the antithesis of free choice to speak out or to remain silent." ${ }^{\text {18 }}$ Like the circumstances in Miranda, the practice of offering the option of losing one's job or making self-incriminating statements is "likely to exert such pressure upon an individual as to disable him from making a free and rational choice." 19 Thus, the Garrity decision protects public employees from self-incrimination by prohibiting the use of statements obtained under threat of removal from employment in subsequent criminal proceedings. ${ }^{20}$

On the same day that the Supreme Court decided Garrity, it also decided Spaveck v. Klein, in which Justice Fortas's concurring opinion noted that the Garrity decision did not stand for the proposition that public employees were immune from being discharged for refusal to testify on

\footnotetext{
${ }^{15} 385$ U.S. 493, 495 (1967).

${ }^{16} I d$.

${ }^{17}$ Id.

${ }^{18} I d$. at 497.

${ }^{19} I d$.

${ }^{20} I d$. at 500.
} 
conduct relative to their employment. ${ }^{21}$ Instead, he stated, the decision in Garrity only rendered the dismissal of a public employee for refusal to testify improper when the government sought to use the testimony in subsequent criminal proceedings. ${ }^{22}$ Thus, where public employees are forced to answer potentially incriminating questions under threat of being fired, such statements cannot be used against them in subsequent criminal proceedings.

\section{Gardner: The Ban on Requiring Waiver of Immunity}

Just over a year later in 1968, the Supreme Court decided Gardner v. Broderick, ${ }^{23}$ which confronted the issue of whether public employees may be fired for refusing to waive their Fifth Amendment Privilege against self-incrimination. The Court reviewed the Garrity and Spaveck decisions and held that if public employees refuse to answer questions "specifically, directly, and narrowly" relating to the performance of their official duties, without being required to waive their immunity in subsequent criminal proceedings, then the privilege against self-incrimination would not bar dismissal from employment. ${ }^{24}$ However, where public employees are discharged from office not for failure to answer relevant questions about their duties as employees, but rather for refusing to waive a constitutional right, such discharge is improper because it violates the rights and immunities afforded to citizens under the Fifth Amendment. ${ }^{25}$ Therefore, the practice of presenting public employees with a choice between job loss and self-incrimination is unconstitutional, regardless of its effectiveness. ${ }^{26}$

\footnotetext{
${ }^{21} 385$ U.S. 511, 519 (1967) (Fortas, J., concurring).

${ }^{22} I d$.

${ }^{23} 392$ U.S. 273.

${ }^{24}$ Id. at 278.

${ }^{25} I d$.

${ }^{26} I d$.
} 


\section{Lekowitz I \& II: The Limited Expansion of Public Employee Rights and Immunities}

Finally, the last two Supreme Court cases related to public employee Fifth Amendment rights and immunities were decided in the 1970s. The first case, Lefkowitz v. Turley (Lefkowitz I), addressed the issue of whether public contractors are afforded the same rights and immunities as public employees when presented with the choice between waiving their Fifth Amendment rights against self-incrimination and losing their contracts with the government. ${ }^{27}$ The Court held such a practice is indeed unconstitutional, and reasoned that there was no difference between the threat of job loss to a public employee and threat of loss of contracts to a contractor who is engaged in business with the government. ${ }^{28}$ Essentially, the Court found that such a threat amounts to coercion because the choice presented to the contractors threatened their livelihood. ${ }^{29}$ As a result, any incriminating statements elicited as a result of that coercion could not be used against the contractors in any subsequent criminal proceeding, regardless of any governmental need for such statements. ${ }^{30}$

The Supreme Court further expanded the concept of public employee immunity in Lefkowitz v. Cunningham (Lefkowitz II) when it addressed the issue of whether public employers may sanction or discipline public employees for refusing to waive their constitutional privilege against self-incrimination as long as the sanctions do not have economic ramifications. ${ }^{31}$ The Court in Lefkowitz II specifically addressed whether a political party officer could be sanctioned and prevented from holding further office for refusing to waive the Fifth Amendment protection

\footnotetext{
${ }^{27} 414$ U.S. 70, 82 (1973).

${ }^{28} I d$. at 83 .

${ }^{29} I d$.

${ }^{30} I d$.

${ }^{31} 431$ U.S. 801, 802 (1977).
} 
against self-incrimination. ${ }^{32}$ The Court held that where public employees are sanctioned or disciplined for refusing to waive their privilege against compelled self-incrimination without being tendered immunity from those statements, such practices amount to coercion and a violation of the Fifth Amendment. ${ }^{33}$ Therefore, unless public employees are immunized from subsequent criminal prosecution, any statements procured through threats of discipline, sanction or loss of employment for failure to waive the right of self-incrimination amount to coercion and are unconstitutional.

\section{THE NOTICE PROBLEM}

Although the Supreme Court made it clear that public employees cannot be constitutionally coerced to waive their privilege against self-incrimination without being granted immunity from subsequent criminal prosecution, the Court has been less clear as to whether a public employer has a duty to provide employees with notice of their rights and immunities. To date, six federal circuit courts have addressed the issue of whether a public employer must give public employees notice of their rights and immunities prior to asking potentially incriminating questions. The Fifth $^{34}$, Eighth $^{35}$, and Eleventh ${ }^{36}$ circuits have adopted the "no affirmative tender" approach and held that there is no notice requirement because the right to immunity attaches automatically when a public employee is compelled to waive their right to silence. ${ }^{37}$ This approach emphasizes that it is the threat of discipline or job loss that creates the constitutional protection of immunity

\footnotetext{
${ }^{32} I d$.

${ }^{33} I d$. at 806 .

${ }^{34}$ Gulden v. McCorkle, 680 F.2d 1070 (5th Cir. 1982).

${ }^{35}$ Hill v. Johnson, 160 F.3d 469 (8th Cir. 1988).

${ }^{36}$ Hester v. Milledgeville, 777 F.2d 1492 (11th Cir. 1985).

${ }^{37}$ Hill at $471-472$.
} 
and bars the answers from being used in subsequent proceedings, not the affirmative notice of immunity. ${ }^{38}$ Conversely, the Second ${ }^{39}$, Seventh ${ }^{40}$, and Federal ${ }^{41}$ circuits have adopted the "duty to advise" approach and held that prior to asking potentially incriminating questions, public employers must advise public employees that they may not refuse to answer the questions under the guise that the questions may be incriminating because they are entitled to immunity from subsequent prosecution. ${ }^{42}$ This approach emphasizes that the disclosure obligation is essential because it protects public employees who may not be well versed with the complex exceptions to the Garrity decision. ${ }^{43}$

\section{A. "No Affirmative Tender" Approach}

As stated above, the Fifth, Eighth, and Eleventh circuits adopt the "no affirmative tender" approach, which rejects a requirement for an affirmative tender of immunity to public employees prior to requiring them to answer potentially incriminating questions. In the Fifth Circuit case Gulden v. McCorkle, the Dallas Public Works Department (the "Department") sought to require its employees, including Charles Gulden and Richard Sage, to take a polygraph examination in connection with an investigation about a bomb threat. ${ }^{44}$ In the process of conducting the mandatory polygraph tests, the Department required employees to sign two waivers, one of

\footnotetext{
${ }^{38}$ Gulden at 1075 .

${ }^{39}$ Uniformed Sanitation Men Ass'n v. Commissioner of Sanitation of the City of New York, 426 F.2d 619 (2nd Cir. 1970).

${ }^{40}$ Atwell v. Lisle Park District, 286 F.3d 987 (7th Cir. 2002).

${ }^{41}$ Modrowski v. Dept. of Veterans Affairs, 252 F.3d 1344 (Fed. Cir. 2001).

${ }^{42}$ Id. at 1351 (Fed. Cir. 2001).

${ }^{43}$ Atwell at 990.

${ }^{44} 680$ F.2d 1070, 1071 (1982).
} 
which stated that the employees were not being promised immunity in an effort to induce them to consent to the examination. ${ }^{45}$ However, upon being brought in for the examination, Gulden and Sage refused to either sign the waiver or submit to the polygraph, and as a result were fired. ${ }^{46}$

As a result, Gulden and Sage sued in the District Court for the Northern District of Texas. ${ }^{47}$ After a bench trial, the district court found for the Department and held that Gulden and Sage's Fifth Amendment rights against self-incrimination were not violated because the polygraph examinations were purely job-related and the waiver sought only to obtain consent to take the polygraph. ${ }^{48}$ The court explained that the Fifth Amendment does not require an affirmative tender of immunity, but only requires that employees be advised that evidence obtained as a result of the polygraph may be used against them, and that they may not be dismissed for refusing to waive their right against self-incrimination. ${ }^{49}$

The Fifth Circuit Court of Appeals affirmed the district court decision and held that public employers violate the Fifth Amendment rights of public employees only when the employees are both coerced to answer potentially incriminating questions and required to waive their right to immunity. ${ }^{50}$ As such, a public employer's actions are unconstitutional if an employee's discharge is predicated on his or her refusal to waive immunity. ${ }^{51}$ Moreover, there is no constitutional violation where an employee's discharge is based on refusing to answer if there is no demand by

\footnotetext{
${ }^{45}$ Id. at 1072 .

${ }^{46} I d$.

${ }^{47} I d$. at 1073.

${ }^{48} I d$.

${ }^{49}$ Id.

${ }^{50} I d$. at 1074.

${ }^{51}$ Id.
} 
the employer for the employee to relinquish the constitutional right to immunity. ${ }^{52}$ The court further held that there was no requirement for an affirmative tender of immunity because an explicit coercive demand by the employer that employees waive immunity or lose their job is what creates the constitutional problem, not the fact that the employee was never warned. ${ }^{53}$ Thus, the Fifth Circuit rejected the notion that government employers should be required to give an affirmative tender of immunity to public employees when asking potentially incriminating questions because immunity attaches automatically as a result of the compulsion, not because the employees were notified of their rights. ${ }^{54}$

Like the Fifth Circuit, the Eighth Circuit has also adopted the "no affirmative tender" approach, which supports automatic attachment of immunity to the public employee. In Hill $v$. Johnson, J.D. Hill, a supervising officer at the Sheriff's department, filed suit in the District Court for the Eastern District of Arkansas against the Sheriff of Pulaski County (the "Sheriff") for violating his Fifth Amendment rights and immunities. ${ }^{55}$ After discovering that a photograph of a beaten detainee had gone missing, the Sheriff sought to question Hill about the incident and subject him to a polygraph examination. ${ }^{56}$ However, Hill refused to answer the questions and failed to appear for the polygraph examination. ${ }^{57}$ Subsequently, the Sheriff terminated Hill's employment, which prompted Hill to file suit. ${ }^{58}$ Ultimately, the district court denied the

\footnotetext{
${ }^{52} I d$.

${ }^{53} I d$.

${ }^{54} I d$.

${ }^{55} 160$ F.3d 469, 470 (8th Cir. 1998).

${ }^{56} I d$.

${ }^{57} I d$.

${ }^{58}$ Id.
} 
Sheriff's motion for summary judgment, which alleged that no constitutional or statutory right was violated. ${ }^{59}$

On appeal, the Eighth Circuit reversed the district court's denial of summary judgment, holding that Hill failed to allege a "violation of clearly established Fifth Amendment rights of which a reasonable person would have known." ${ }^{90}$ The court reasoned that because there is a substantial "public interest in securing from public employees an accounting of their public trust," a government employer does not violate a public employee's constitutional rights as long as the employer does not demand that the employee relinquish his constitutional immunity from prosecution. ${ }^{61}$ Thus, so long as the employer does not require the employee to waive immunity, it can compel the employee to either testify about the performance of official duties or forfeit employment. $^{62}$

The Eighth Circuit reinforced this holding and specifically rejected an employer's duty to affirmatively offer immunity. Citing Gulden, the court found that even if employees are not specifically informed that their answers could not be used against them in subsequent criminal prosecution, "the mere failure affirmatively to offer immunity is not an impermissible attempt to compel a waiver of immunity." ${ }^{, 63}$ As such, regardless of whether public employees are given notice of their rights and immunities, a public employer's actions are constitutional as long as the employees are not expressly asked to waive immunity rights on penalty of job loss, and any statements procured from them are not used against them in subsequent prosecution.

\footnotetext{
${ }^{59} I d$.

${ }^{60} I d$. at 471.

${ }^{61} I d$.

${ }^{62} I d$.

${ }^{63} I d$.
} 
Like the Fifth and Eighth Circuits, the Eleventh Circuit has also adopted the "no affirmative tender" approach. In Hester v. Milledgeville, Freddie Hester brought an action in the District Court for the Middle District of Georgia against the City of Milledgeville (the City"), challenging the constitutionality of the City's practice of requiring firefighters to submit to polygraph examinations. ${ }^{64}$ When the polygraph testing was implemented, the firefighters were required to sign one of four forms prior to taking the polygraph. ${ }^{65}$ In the first form, the employee consented to the use of the result in a subsequent judicial proceeding or administrative hearing. ${ }^{66}$ In the second form, the employee waived all state and federal constitutional rights in connection with the polygraph. ${ }^{67}$ In the third form, the employee retained all constitutional rights and the permission to object to incriminating questions. ${ }^{68}$ In the fourth form, the employee refused to submit to the polygraph examination. ${ }^{69}$ Although Hester was never tested because the City agreed to postpone testing until the legality of the procedure was determined in court, he filed suit challenging the constitutionality of the requirement. ${ }^{70}$ The district court found for Hester, and issued a permanent injunction on the polygraph testing on the premise that the waiver system had the potential to violate rights of self-incrimination, due process, and privacy. ${ }^{71}$

\footnotetext{
${ }^{64} 777$ F.2d 1492 (11th Cir. 1985).

${ }^{65} I d$.

${ }^{66} I d$.

${ }^{67} I d$.

${ }^{68} I d$.

${ }^{69} I d$.

${ }^{70} I d$.

${ }^{71} I d$.
} 
On appeal, the Eleventh Circuit affirmed the decision of the district court and upheld the injunction against the polygraph testing. ${ }^{72}$ The court reasoned that because the City had no authority to require at least two of the waiver options, Hester and the other public employees would be in an inherently coercive situation. ${ }^{73}$ The court found that if it is unconstitutional for a public employer to compel a public employee to answer self-incriminating questions without immunity, it follows that if a public employee is compelled to give such self-incriminating evidence, that evidence could not be used in a subsequent criminal proceeding. ${ }^{74}$ As such, the court held that a notice requirement would serve "no useful purpose. ${ }^{75}$ Thus, no affirmative tender of immunity is necessary because the right to immunity after compelled testimony automatically attaches. ${ }^{76}$

Therefore, the Fifth, Eighth, and Eleventh Circuits have all developed a "no affirmative tender" approach, which refuses to require public employers to provide public employees with notice of their rights and immunities prior to being asked potentially incriminating questions. The Fifth Circuit reasoned that no notice is required because it is the coercive nature of the choice between compelled testimony and job forfeiture that automatically attaches the right to immunity under the Fifth Amendment. The Eighth Circuit reasoned that no affirmative tender of immunity is required because there is no constitutional violation unless the public employees are expressly asked to waive their immunity rights or the information is actually used against them in subsequent prosecution. Finally, the Eleventh Circuit reasoned that there is no notice

\footnotetext{
${ }^{72} I d$.

${ }^{73}$ Id. at $1495-1496$.

${ }^{74}$ Id. at 1496.

${ }^{75} I d$.

${ }^{76} I d$.
} 
requirement because it is implied in Garrity that if it is unconstitutional to compel selfincrimination by a public employee without immunity, any testimony that is procured from compelled testimony could not be used in a subsequent criminal proceeding. Thus, the Fifth, Eighth, and Eleventh Circuits found that the government has no duty to provide public employees with notice of their rights and immunities under the Fifth Amendment because immunity automatically attaches in coercive situations, causing the notice requirement to serve no legitimate purpose.

\section{B. The "Duty to Advise" Approach}

Alternatively, the Second ${ }^{77}$, Seventh ${ }^{78}$, and Federal ${ }^{79}$ Circuits have adopted the "duty to advise" approach. Under this approach, a public employer has an affirmative duty to advise public employees about their Fifth Amendment rights and immunities prior to asking potentially incriminating questions. In the Second Circuit Case Uniformed Sanitation Men Ass' $n v$. Commissioner of Sanitation of the City of New York, The City Department of Sanitation Employees (the "Employees") sued the Commissioner of Sanitation of New York City (the "Commissioner") in the District Court for the Southern District of New York seeking reinstatement from being fired after refusing to answer potentially incriminating questions. ${ }^{80}$ In 1966, the City of New York required private waste carriers to purchase tickets for the privilege of using the City's waste disposal facilities. ${ }^{81}$ As a result, the Department of Uniformed

\footnotetext{
${ }^{77}$ Uniformed Sanitation Men Ass'n v. Commissioner of Sanitation of the City of New York, 426 F.2d 619 (2nd Cir. 1970).

${ }^{78}$ Atwell v. Lisle Park District, 286 F.3d 987 (7th Cir. 2002

${ }^{79}$ Modrowski v. Dept. of Veterans Affairs, 252 F.3d 1344 (Fed. Cir. 2001).

${ }^{80} 426$ F.2d 619, 622 (2nd Cir. 1970).

${ }^{81} I d$. at 621.
} 
Sanitation was charged with the responsibility of selling those tickets. ${ }^{82}$ However, in the course of business, the Commissioner learned that some Employees were selling the tickets for cash and pocketing the profit. ${ }^{83}$ Therefore, the Commissioner initiated an investigation, which included observation by detectives and wiretapping of telephones. ${ }^{84}$

The Deputy Administrator of the Environmental Protection Administration, which included the Department of Sanitation, called the Employees in for questioning. ${ }^{85}$ At the meeting, all the Employees were represented by counsel and advised by the Deputy Administrator of their "rights and privileges" under the laws of New York and the Constitution. ${ }^{86}$ When the Employees refused to answer any incriminating questions, the Commissioner suspended them. ${ }^{87}$ Eventually, the Commissioner gave the Employees a second opportunity to answer, but when the Employees subsequently refused, they were fired. ${ }^{88}$ The Employees then filed suit and demanded reinstatement on the ground that their Fifth Amendment rights and immunities had been violated. ${ }^{89}$ Both parties then filed motions for summary judgment, and the district court found for the Employees. ${ }^{90}$

\footnotetext{
${ }^{82} I d$.

${ }^{83} I d$.

${ }^{84} I d$.

${ }^{85} I d$. at 621.

${ }^{86}$ Id.

${ }^{87}$ Id.

${ }^{88} I d$. at 622 .

${ }^{89} \mathrm{Id}$.

${ }^{90} \mathrm{Id}$.
} 
On appeal, the Second Circuit reversed the district court's decision and held that compelled testimony is constitutional so long as the questions posed by the government employer to public employees are about performance of their official duties and the employees are duly advised of their rights and immunities prior to questioning. ${ }^{91}$ The court reaffirmed the rule that if public employees are asked potentially incriminating questions and are not required to waive immunity, the privilege against self-incrimination is not a bar to his dismissal for refusal to answer. ${ }^{92}$ However, the court also expressly included the requirement that public employers advise public employees of their rights and immunities, as well as the consequences of their decisions prior to asking potentially incriminating questions. ${ }^{93}$ Thus, the Second Circuit's decision in Uniformed Sanitation Men stands for three propositions. First, prior to asking potentially incriminating questions, government employers must advise public employees of their rights and immunities under the Fifth Amendment. ${ }^{94}$ Second, if employees who have been duly advised of their rights and immunities refuse to answer the government employer's questions, the employer may constitutionally fire the employees. ${ }^{95}$ Third, if employees are duly advised of their rights and immunities and consent to answer the questions instead of face disciplinary action, those answers cannot be used against them in subsequent criminal proceedings. ${ }^{96}$

Like the Second Circuit, the Seventh Circuit also adopts the "duty to advise" approach, which requires a government employer to give public employees notice of their rights and

\footnotetext{
${ }^{91} I d$. at 627.

${ }^{92} I d .626$.

${ }^{93} I d$. at 627.

${ }^{94} I d$.

${ }^{95} I d$.

${ }^{96} I d$.
} 
immunities prior to asking potentially incriminating questions. In Atwell v. Lisle Park Dist., Sarah Atwell brought an action in the District Court for the Northern District of Illinois against the Lisle Park District (the "Park District") alleging that her Fifth Amendment rights were violated because the Park District terminated her for failure to cooperate with the investigation. ${ }^{97}$ Due to a series of financial improprieties, the Park District initiated an investigation and suspended Atwell. ${ }^{98}$ In response, Atwell obtained counsel. ${ }^{99}$ However, prior to the questioning and in the course of an informal meeting, the investigator for the Park District informally instructed Atwell that her attorney would probably advise her to exercise her right to remain silent. ${ }^{100}$ As predicted, Atwell's attorney advised her to refuse to consent to an interview and Atwell complied. The Park District then fired Atwell. ${ }^{101}$ Atwell sued, but the district court dismissed her case. ${ }^{102}$

On appeal, the Seventh Circuit cited the Garrity rule that a government employer may compel a public employee to answer potentially incriminating questions upon penalty of job loss or disciplinary action only if that employee is not required to waive immunity. ${ }^{103}$ The court affirmed the district court's decision to dismiss on the ground that the duty to advise never arose because Atwell never attended the interview. ${ }^{104}$ However, on the issue of notice, the court found

\footnotetext{
${ }^{97} 286$ F.2d 987 (7th Cir. 2002).

${ }^{98}$ Id. at 989.

${ }^{99} I d$.

${ }^{100} \mathrm{Id}$.

${ }^{101}$ Id.

${ }^{102}$ Id.

${ }^{103}$ Id. at 990.

${ }^{104}$ Id.
} 
that a government employer who seeks to ask employees potentially incriminating questions must first warn the employees that because of the Garrity immunity, they may not refuse to answer the questions on the basis that the answers may be incriminating. ${ }^{105}$ The court reasoned that employees who are asked potentially incriminating questions may "instinctively 'take the Fifth", and unknowingly set themselves up to get fired without recourse. ${ }^{106}$ Ultimately, the Seventh Circuit maintained an express notice requirement, but emphasized that the rule was limited by the fact that "there can be no duty to warn until the employee is asked specific questions," and that given this limitation the employee may not skip the interview altogether in an effort to avoid answering incriminating questions. ${ }^{107}$

Like the Second and Seventh Circuits, the Federal Circuit also follows the rule that a government employer must warn its employees of their rights and immunities prior to asking potentially incriminating questions. In Modrowski v. Dept. of Veterans Affairs, the circumstances were somewhat different than the typical Fifth Amendment employment case. ${ }^{108}$ There, the Department of Veterans Affairs (the "DVA") employed Leon Modrowski as a Senior Realty Specialist in Chicago, Illinois. ${ }^{109}$ During that employment, the DVA began an internal investigation into the theft of property from houses owned by the DVA. ${ }^{110}$ In the course of this investigation, the DVA questioned Modrowski, and discovered that he had participated in two

\footnotetext{
${ }^{105} I d$.

${ }^{106} \mathrm{Id}$.

${ }^{107}$ Id. at 991.

${ }^{108} 252$ F.3d 1344 (Fed. Cir. 2001).

${ }^{109} I d$. at 1346.

${ }^{110} I d$.
} 
unauthorized sales of property to his son-in-law, which was against DVA regulations. ${ }^{111}$ Consequently, the DVA conducted a series of follow-up investigations on Modrowski, and in so doing sent him a letter that purported to grant him immunity, advised him of his Fifth Amendment rights, and compelled him to respond to questioning. ${ }^{12}$ However, Modrowski did not understand the scope of the purported immunity and thus continually refused to answer any questions during subsequent interrogations. ${ }^{113}$ Thereafter, Modrowski obtained counsel and continued to refuse to waive his right to silence. ${ }^{114}$ Ultimately, the DVA discharged Modrowski from federal service on the grounds that he violated conflict of interest rules, and more specifically failed to cooperate with the investigation. ${ }^{115}$ Accordingly, the Board affirmed the DVA's decision to discharge Modrowski. ${ }^{116}$ As such, Modrowski appealed to the Federal Circuit. ${ }^{117}$

On appeal, the Federal District reversed the Board's decision regarding Modrowski's refusal to submit to interrogation by the DVA. ${ }^{118}$ The court referred to the Garrity rule and held that the threat of discharge from public employment constitutes coercion, making any statements obtained as a result of such threat inadmissible against that employee in subsequent criminal

\footnotetext{
${ }^{111} I d$.

${ }^{112} I d$. at 1347.

${ }^{113} I d$.

${ }^{114}$ Id. at 1348 .

${ }^{115}$ Id.

${ }^{116} I d$

${ }^{117}$ Id.

${ }^{118} I d$. at 1353 .
} 
proceedings. ${ }^{119}$ Moreover, the court also held that a government employer may only properly invoke the right to compel answers to pertinent questions about the performance of the employee's duties when the employee has been duly advised of the option to answer when actually granted immunity, or remain silent and face discharge. ${ }^{120}$ However, where the immunity granted by the public employer is not as comprehensive as the protection of the Fifth Amendment privilege, that employee is justified in refusing to answer potentially incriminating questions. ${ }^{121}$ Thus, the court decided that Modrowski was justified in refusing to answer the DVA's questions because the scope of the purported grant of immunity was ambiguous, leaving open the possibility that any answers elicited during that questioning could be used against him in subsequent proceedings. ${ }^{122}$

Therefore, the Second, Seventh, and Federal Circuits have all developed a "duty to advise" approach, which requires government employers to inform employees of their Fifth Amendment rights and immunities, as well as the consequences of their decisions prior to being asked potentially incriminating questions. The Second Circuit held that public employees may only be discharged for failure to cooperate while under the cloak of immunity if they are duly advised of their rights and immunities prior to being asked specific pertinent questions about their duties of employment. ${ }^{123}$ In adopting this approach, the Seventh Circuit reasoned that because average employees are likely to exercise their Fifth Amendment right to remain silent they may unknowingly subject themselves to discharge without recourse if they are not first advised of

\footnotetext{
${ }^{119} I d$. at 1350 .

${ }^{120} \mathrm{Id}$. at 1351.

${ }^{121} I d$. at 1252 .

${ }^{122} I d$.

${ }^{123}$ Uniformed Sanitation Men Ass' $n$ at 627.
} 
their rights and immunities under the Fifth Amendment. ${ }^{124}$ The Federal Circuit reinforced this concept and held that in order for notice to be constitutionally sufficient, the government employer must clearly advise employees of their rights and immunities in such a manner that the scope of immunity is broad enough to match the protection afforded by the Fifth Amendment. ${ }^{125}$

\section{ANALYSIS}

As stated above, the Supreme Court decisions in Garrity and its progeny stand for the proposition that under the Fifth Amendment, public employees must be granted immunity from subsequent criminal prosecution if they are coerced into answering potentially incriminating questions. However, the federal courts have split on the issue of whether a government employer must give employees notice of their rights and immunities under the Fifth Amendment prior to asking potentially incriminating questions. The "no affirmative tender" approach of the Fifth, Eighth, and Eleventh Circuits attempts to lessen the government's burden and support the employer's interest in reliable evidence by automatically attaching the right of immunity when an employee is compelled to answer incriminating questions. The courts reason that such a notice requirement would be duplicative because the right to immunity attaches regardless of whether notice is given. Thus, under this approach, if public employees are coerced into answering incriminating questions on threat of discipline or job loss, those answers cannot be used against them in subsequent proceedings. Additionally, if public employees refuse to answer the questions without expressly being asked to waive their right to immunity, then the employer may discharge them for failure to cooperate.

\footnotetext{
${ }^{124}$ Atwell at 990.

${ }^{125}$ Modrowski at 1351, 1352.
} 
However, this approach has two major problems. First, by rejecting a notice requirement, the rule creates ambiguity with respect to employee actions. For example, although the approach expressly permits employees to be fired for refusing to answer questions if they have not been asked to waive their immunity, it does not address the issue of whether discharge or discipline is appropriate where employees remain silent based on an "objectively reasonable fear" that their answers could be used against them in subsequent criminal proceedings. ${ }^{126}$ As such, it is entirely possible that public employees could be discharged or disciplined solely because they are unaware of their rights and the consequences of their decision to remain silent. ${ }^{127}$ In essence, without a notice requirement, public employees could unknowingly subject themselves to sanctions by exercising their Fifth Amendment privilege against self-incrimination.

Second, this approach gives the government an extraordinary amount of room in which to take advantage of the employee. Because the rule permits the government to fire employees for exercising their right to silence if they are not required to waive immunity, there is potential that the government could abuse its position as the more knowledgeable and powerful party. ${ }^{128}$ In essence, by not disclosing what the employee's rights and obligations are under Garrity and the Fifth Amendment, the employer leaves the employee in a state of ambiguity that can easily be exploited. As such, if it is not clear to public employees what their constitutional rights are, how their statements could be used against them, and how to respond to the often vague requests of employers to submit to questioning or polygraph interrogations, the employer could reasonably manipulate the situation so that the employees get fired or prosecuted, regardless of whether they

\footnotetext{
${ }^{126}$ Sher v. U.S. Dep’t of Veterans Affairs, 488 F.3d 489, 511 (1st Cir. 2007) (Stahl, J., dissenting).

${ }^{127} \mathrm{Id}$.

${ }^{128} I d$.
} 
answer the questions or not. This sort of imbalance in power should not be constitutionally permitted.

In contrast, the "duty to advise" approach of the Second, Seventh, and Federal Circuits seeks to eliminate ambiguity and further the protections afforded in Garrity, by requiring government employers to fully disclose to employees their rights and immunities prior to subjecting them to potentially incriminating questioning. This approach, which emphasizes the protective nature of Garrity, has four crucial advantages.

First, by requiring employers to warn public employees that they may be fired for refusing to answer potentially incriminating questions if they have been granted immunity, the "duty to advise" approach eliminates the confusion created by the "no affirmative tender" approach. Although lack of knowledge in the criminal arena is not a defense for committing a crime, the interplay between the Fifth Amendment and Garrity are such that average public employees may not fully understand their rights. Even though it may be true that public employees are aware of their Fifth Amendment rights, it is more likely to be true that the same employees may not understand the various complex exceptions under Garrity, which is less widely known and understood than the Fifth Amendment. ${ }^{129}$ For example, because this approach expressly provides employees with the knowledge of all of their rights and immunities, there is no longer a risk that the employees will exercise their right to silence and unknowingly lose their job as a consequence of their decision. Thus, the notice requirement permits employees to make informed decisions instead of encouraging them to make blind decisions.

Second, this approach eliminates the potential for government employers to exploit the employee's lack of familiarity with the Fifth Amendment rights and immunities. By requiring

${ }^{129} I d$. 
the employer to fully disclose all of the employee's rights and immunities, as well as the consequences to those decisions, the "duty to advise" approach ensures that the employee is informed and less susceptible to any misrepresentation or deception by the government. Such a requirement makes it more difficult for the government, which is in a position of power, to manipulate the situation into one where employees either get fired or prosecuted, irrespective of whether or not they submit to the questioning. ${ }^{130}$ In so doing, the disclosure requirement furthers the protective nature of Garrity by ensuring that the Fifth Amendment rights and immunities cannot be circumvented by government employers.

Third, the "duty to advise" approach is favorable because the burden imposed on the government employer by the duty of disclosure would be rather low. ${ }^{131}$ In fact, the duty does not even arise until the interrogation takes place. Essentially, the government's duty to disclose never arises if the public employee fails to attend the questioning. Furthermore, there is no indication that the notice requirement must be fact specific. In fact, the Federal Circuit held that notice is sufficient even if the government uses a standardized form, as long as it is clear and fully conveys the public employee's rights. ${ }^{132}$ Therefore, in comparison to the interest of fairness and clarity, the burden of giving notice to public employees prior to questioning is minimal.

Fourth, the "duty to advise" approach is most favorable because it facilitates the government in its mission to obtain reliable information from public employees. Whereas uninformed employees are likely to be untruthful or bend the facts in an attempt to avoid

\footnotetext{
${ }^{130} I d$.

${ }^{131} I d$.

${ }^{132}$ Hanna v. Dep’t of Labor, 18 Fed. Appx. 787, 789-90 (Fed. Cir. 2001).
} 
prosecution, employees who know from the beginning that they are immune from their statements in subsequent prosecution are more likely to give honest answers. Although it is true that the statements may still be used against employees in regard to discipline or discharge by the employer, it is still much more likely that the employees will be honest if they know that those statements cannot be used against them in a subsequent criminal proceeding. Therefore, the "duty to advise" approach is preferable because it reinforces the government's interest in obtaining truthful information from its employees.

\section{CONCLUSION}

Everyday government employers are faced with the task of questioning public employees about potentially incriminating issues. As a general rule, if the government employer seeks to compel employees to answer the questions on penalty of discipline or job loss, employees must also be provided with immunity from use of those statements against them in subsequent proceedings. As such, a government employer cannot constitutionally fire employees for failure to waive their right to immunity. However, although this rule is clear, it fails to specify whether the employer is under a duty to give public employees notice of these rights and immunities prior to interrogation.

As to that question, the federal circuits are split as to whether there is a notice requirement. The first group of circuits adopts the "no affirmative tender" approach, which rejects a notice requirement and automatically attaches immunity when public employees are compelled to waive their right to immunity and answer potentially incriminating questions on penalty of disciplinary action or job loss. The second group of circuits adopts the "duty to advise" approach, which requires government employers to give employees notice of their rights 
and immunities under the Fifth Amendment, as well as the consequences to any decisions they may make.

This article argues that the "duty to advise" approach is the most favorable for four reasons. First, it eliminates the potential for public employees to attempt to exercise their constitutional privilege against self-incrimination and unknowingly subject themselves to discipline. Second, it eliminates the potential that the government will use its position of power to manipulate or exploit the employee. Third, the burden imposed on the government in comparison to the protection afforded to the employees would be inherently low. Fourth, it facilitates the government in the process of fact-finding by giving the employees an incentive for honesty. Therefore, the "duty to advise" approach should be adopted by all circuits. 